\title{
Politik Hukum Penyederhanaan Sistem Kepartaian Di Indonesia
}

\author{
Muhammad Febry Ramadhan \\ mfbry15@yahoo.com
}

\begin{abstract}
The increasing number of political parties after the reform era as the consequence of the protection of the right to freedom of association in the constitution has become a crucial issue considering that the objective of reform and constitutional amendment is to strengthen the presidential system. This is because the presidential system is considered incompatible with the multi-party system. This study aimed to analyze, first, the history of the policies to simplify the party system in Indonesia and, second, the legal politics in determining the parliamentary threshold in Law No. 7 of 2017 as an effort to simplify the party system in Indonesia. Using the normative legal research method and legislative as well as conceptual approaches, this research concluded that, first, after the reform era, several policies have been taken as an effort to simplify the political party system, including by challenging the establishment of political parties, aggravating the requirements for political parties to obtain a legal entity status, imposing more difficult terms through verification for political parties to take part in elections, implementing electoral threshold, and applying the parliamentary threshold. Second, the implementation of parliamentary threshold is deemed effective to simplify the party system in the parliament, thus making the presidential system effective. Therefore, in Law No. 7 of 2017 on General Elections, the new parliamentary threshold is set at $4 \%$ because $3.5 \%$ in the 2014 election had yet to be able to simplify the party system in Indonesia.
\end{abstract}

Keywords: Legal politics; party system; parliamentary threshold

\begin{abstract}
Abstrak
Menjamurnya partai politik pasca reformasi sebagai konsekuensi dari perlindungan hak kebebasan berserikat di dalam konstitusi menjadi isu krusial mengingat cita-cita reformasi dan amandemen konstitusi adalah memperkuat sistem presidensial. Hal ini karena sistem presidensial dianggap tidak kompatibel dengan sistem multi partai. Penelitian ini bertujuan untuk menganalisis pertama, sejarah kebijakan penyederhanaan sistem kepartaian di Indonesia; Kedua, politik hukum penentuan parliamentary threshold dalam Undang-Undang Nomor 7 Tahun 2017 sebagai upaya penyederhanaan sistem kepartaian di Indonesia. Menggunakan metode penelitian hukum normatif, serta pendekatan perundang-undangan dan pendekatan konseptual, penelitian ini menyimpulkan pertama, pasca reformasi, telah ditempuh beberapa kebijakan sebagai upaya penyederhanaan partai politik, di antaranya adalah menerapkan pemberatan pendirian partai politik; memperberat syarat bagi partai politik dalam memperoleh status badan hukum, memperberat partai politik yang akan mengikuti pemilu melalui verifikasi, menerapkan electoral threshold, dan menerapkan ambang batas parlemen (parliamentary threshold). Kedua, penerapan parliamentary threshold dianggap efektif untuk menyederhanakan sistem kepartaian di parlemen, guna mengefektifkan sistem presidensial, karena itu, melalui Undang-Undang Nomor 7 Tahun 2017 tentang Pemilihan Umum, ketentuan parliamentary threshold ditentukan angka baru sebesar 4\%, karena dinilai angka 3,5\% pada pemilu tahun 2014 belum mampu menyederhanakan sistem kepartaian di Indonesia.
\end{abstract}

Kata-kata Kunci: Politik hukum; sistem kepartaian; parliamentary threshold 


\section{Pendahuluan}

Salah satu semangat perubahan Undang-Undang Dasar Negara Republik Indonesia Tahun 1945 (UUD NRI 1945) ialah memperkuat bangunan sistem pemerintahan presidensial. ${ }^{1}$ Hal ini ditandai dengan perumusan Pasal 6A ayat (1), di mana pokok ketentuan yang terkandung di dalamnya menegaskan bahwa mekanisme pengisian jabatan Presiden dan Wakil Presiden ialah dipilih secara langsung oleh rakyat. Bertolak dari ketuntuan tersebut, secara teoretis Indonesia telah mengadopsi salah satu ciri sistem pemerintahan presidensial, dalam bahasa C.F. Strong disebut dengan sistem pemerintahan eksekutif nonparlementer (fixed executive). ${ }^{2}$

Membangun sistem pemerintahan tentu berkaitan erat dengan bangunan sistem kepartaian dan sistem pemilunya. Jika sistem pemerintahan yang dianut Indonesia menurut UUD NRI 1945 adalah sistem pemerintahan presidensial, maka sistem ini harus diturunkan secara konsisten ke dalam pengaturan sistem kepartaian, sistem pemilu legislatif, dan sistem pemilu presiden. ${ }^{3}$ Prakteknya, Indonesia pasca reformasi tidak hanya merubah wajah sistem pemerintahan, namun juga merubah wajah sistem kepartaian. Hal ini ditandai dengan pemberian jaminan kehidupan partai politik, bahkan lebih jauh lagi partai politik didudukkan sebagai organisasi yang mempunyai fungsi penting sebagaimana yang tertuang dalam Pasal 6A ayat (2) dan Pasal 22E ayat (3) UUD NRI 1945, bahwa partai politik adalah organisasi peserta pemilu dan organisasi yang memiliki hak untuk mengajukan pasangan calon presiden dan wakil presiden sekaligus DPR dan DPRD. Pada saat yang bersamaan, partai politik di Indonesia selalu bertumbuh dari waktu ke waktu dengan pijakan konstitusi yang merujuk pada perlindungan hak-hak warga negara sebagaimana diatur dalam Pasal 28 UUD NRI 1945 dalam konteks kemerdekaan berserikat. Bahwa partai politik diyakini sebagai tonggak

${ }^{1}$ Jimly Ashiddiqie, Membangun Budaya Sadar berkonstitusi Untuk mewujudkan Hukum Yang Demokrasi, Bahasa Orasi Ilmiah Disampaikan Pada peringatan Dies Natalis ke XXl dan wisuda 2007 Universitas Darul Ulum (Unisda) Lamongan, 29 Desember 2007

${ }^{2}$ C.F Strong, Konstitusi-Konstitusi Politik. Modern, Cetakan Sepuluh, Nusa Media, Bandung, 2015, hlm. 355.

${ }^{3}$ Ni'matul Huda dan Imam Nasef, Penataan Demokrasi dan Pemilu di Indonesia Pasca-Reformasi, Edisi Pertama Fajar Interpratama Mandiri, Jakarta, 2017, hlm. 38. 
demokrasi yang dapat menentukan pemimpin Negara Republik Indonesia, yang mempunyai sistem pemerintahan presidensial. ${ }^{4}$ Padahal, sistem presidensial dengan banyaknya partai politik dianggap bukan merupakan pilihan yang ideal.

Presiden dalam sistem presidensial tetap memerlukan dukungan dari legislatif. Tanpa dukungan itu presiden akan menghadapi situasi sulit yang mengancam stabilitas pemerintahan. Hanya saja dukungan legislatif sulit didapatkan jika sistem presidensial dibangun dalam sistem multipartai. Selain itu, presiden juga membutuhkan koalisi bila partai pendukung presiden bukanlah partai mayoritas di lembaga perwakilan. Langkah itu dilakukan agar presiden mendapat dukungan mayoritas di lembaga perwakilan. Namun demikian, Scott Mainwaring menilai bahwa membentuk koalisi dalam sistem presidensial merupakan hal yang sulit, dan akan bertambah sulit bila sistem kepartaian yang diterapkan adalah multipartai. ${ }^{5}$

Pada konteks Indonesia, persoalan di atas muncul karena Indonesia menerapkan sistem multipartai di bawah sistem pemerintahan presidensial. Sistem multipartai cenderung membuat presiden tergantung pada partai lain di lembaga legislatif untuk menghindari kebuntuan dan konflik dengan lembaga legislatif. Hal ini tercermin dari praktik hubungan antar lembaga kepresidenan dengan legislatif yang berjalan tidak sesuai dengan ruh UUD NRI 1945 pasca perubahan yang berupaya memberlakukan sistem presidensial secara lebih murni ketimbang sebelumnya. ${ }^{6}$

Sistem multipartai yang diterapkan saat ini tidak mampu menghasilkan lembaga legislatif yang solid karena perolehan kursi di DPR terdistribusi oleh banyak partai dengan kepentingan politik dan ideologi yang berbeda-beda. Akhirnya, karena presiden (dan parpol pendukungnya) tidak mampu memperoleh kursi mayoritas di DPR sehingga presi den yang mendapat mandate langsung dari rakyat melebihi perolehan suara politik ini terpaksa untuk menempuh koalisi besar parpol di parlemen guna mengamankan kebijakan-kebijakannya. ${ }^{7}$

\footnotetext{
${ }^{4}$ Kuswanto, "Penyederhanaan Partai Politik Dalam Sistem Pemerintahan Presidensiil Yang Multipartai", Jurnal Yuridika, Vol. 28, No. 2, 2013, hlm. 1

${ }^{5}$ Khairul Fahmi, Pemilihan Umum Dalam Transisi Demokrasi, Cetakan Pertama, PT RajaGrfindo Persada, Jakarta, 2016, hlm. 1.

${ }^{6}$ Ibid

${ }^{7}$ Kuswanto, Konstitusionalitas Penyederbanaan Partai Politik: Pengaturan Penyederbanaan Partai Politik Dalam Demokrasi Presidensial, Setara Press, Malang, 2016, hlm. 1
} 
Berdasarkan uraian di atas, agar sistem presidensial betul-betul dapat berjalan efektif, tentunya sistem multipartai sebagai rintangan utama harus dibenahi. Terkait masalah tersebut, Scott Mainwaring kembali menegaskan, "the combination of a fractionalized party system and presidentialism is inconductive to democratic stability because it easily creates difficulties in the relationship between the president and the conress". Pendapat ini menggambarkan betapa sistem multipartai dan sistem presidensial teramat sulit digabungkan. Apabila DPR diisi oleh banyak partai, ini akan menyebabkan ruang ketegangan antara eksekutif dan legislatif terbuka lebar. Pada akhirnya, ketidakstabilan pemerintahan pun menjadi konsekuensi yang tak terelakkan. ${ }^{8}$ Penyederhanaan partai politik merupakan pilihan yang tidak dapat dielakkan bila masih ingin tetap konsisten menggunakan sistem presidensial yang sudah dipilih. Namun penyederhanaan tersebut mesti dilakukan dalam kerangka yang diperbolehkan secara konstitusional. ${ }^{9}$

Agar proses penyederhanaan parpol dapat berjalan secara konstitusional maka harus dipilih cara yang juga dapat diterima secara konstitusional. Salah satu instrumen yang dapat digunakan untuk bermetamorfosinya sistem kepartaian adalah parliamentary threshold. Parliamentary threshold diyaini dapat mengurangi jumlah partai politik yang akan masuk ke lembaga perwakilan sehingga akan terjadi penyederhanaan jumlah partai di DPR. Dengan jumlah partai yang lebih sedikit, daya topang sistem kepartaian terhadap bangunan sistem presidensial yang dianut akan lebih kuat.10

\section{Rumusan Masalah}

Berdasarkan latar belakang masalah yang telah dikemukakan di atas, maka peneliti menarik adanya rumusan masalah sebagai berikut: pertama, bagaimana sejarah kebijakan penyederhanaan sistem kepartaian di Indonesia? Kedua, bagaimana politik hukum penentuan parliamentary threshold dalam Undang-

\footnotetext{
${ }^{8}$ Khairul Fahmi, Pemilihan..., Op., Cit., hlm. 10

${ }^{9}$ Ibid., hlm. 6

${ }^{10}$ Ibid
} 
Undang No. 7 Tahun 2017 sebagai upaya penyederhanaan sistem kepartaian di Indonesia?

\section{Tujuan Penelitian}

Sebagai tindak lanjut dari rumusan masalah yang telah ditetapkan di atas, maka tujuan dalam penelitian ini adalah: pertama, untuk mengkaji dan mengetahui sejarah kebijakan penyederhanan sistem kepartaian di Indonesia sejak era reformasi hingga sekarang. Kedua, untuk menganalisis politik hukum penentuan parliamentary threshold dalam Undang-Undang No. 7 Tahun 2017 sebagai upaya penyederhanaan sistem kepartaian di Indonesia.

\section{Metode Penelitian}

Penelitian ini dikualifikasikan ke dalam penelitian hukum normatif. Pendekatan yang digunakan adalah pendekatan konseptual dan pendekatan perundang-undangan. Sumber data yang digunakan adalah data sekunder yang terdiri dari bahan hukum primer berupa UUD NRI 1945 dan Undang-Undang No. 7 Tahun 2017; bahan hukum sekunder berupa literatur, buku, jurnal, dan hasil penelitian terdahulu yang berkaitan dengan topik penelitian; dan bahan hukum tersier. Bahan hukum dianalisis secara deskriptif kualitatif.

\section{Hasil Penelitian dan Pembahasan}

\section{Sejarah Kebijakan Penyederhanaan Sistem Kepartaian Di Indonesia}

Pasca reformasi 1998, pemerintahan transisi dibawah Presiden Habibie kemudian melakukan berbagai perubahan perundangan termasuk di dalamnya undang-undang yang mengatur tentang partai politik dan pemilu. Dua undangundang penting yang diterbitkan di bawah pemerintah B.J. Habibie, yang kemudian menjadi dasar berlakunya sistem multipartai ekstrim dalam pemilu dan parlemen Indonesia pasca orde baru adalah Undang-Undang No. 2 Tahun 1999 tentang Partai Politik dan Undang-Undang No. 3 Tahun 1999 tentang Pemilu. 
Dengan kedua undang-undang inilah pemilu 1999, pemilu pertama di era reformasi digelar. ${ }^{11}$

Kebijakan reformasi B.J. Habibie adalah persetujuannya dengan kehendak publik untuk melaksanakan pemilu secepatnya di 1999 yang didahului dengan Sidang Istimewa MPR guna mencabut TAP MPR No. III Tahun 1998 tentang GBHN yang menyatakan bahwa pemilu berikutnya dilaksanakan 2002.12 Pasal 1 angka 5 Ketetapan MPR RI No. XIV/MPR/1998 menentukan: "pemilu yang dimaksud dalam ketetapan ini diikut oleh partai-partai politik yang telah memenuhi persyaratan sesuai dengan peraturan perundang-undangan yang berlaku serta mempunyai kedudukan, hak dan kewajiban yang sama." Sidang Istimewa yang digelar November 1998 itu menghasilkan 12 TAP MPR yang menjadi landasan reformasi politik, hukum, dan ekonomi. ${ }^{13}$

Presiden B.J Habibie dalam sidang Paripurna DPR 5 Januari 1999 dengan agenda Keterangan Pemerintah tentang RAPBN 1999-2000 menyambut positif langkah reformasi politik di bidang kepartaian tersebut : "pemberian kesempatan munculnya partai-partai baru yang pada gilirannya akan menghasilkan sistem multipartai, merupakan respon kita terhadap luasnya tuntutan masyarakat akan kebebasan politik. Dalam era reformasi ini, kebebasan politik memang harus dijamin dan diatur dalam serangkaian produk perundang-undangan."14

Di antara produk-produk hukum bidang politik yang dibuat di era kekuasaan B.J. Habibie adalah Undang-Undang No. 2 Tahun 1999 tentang partai politik, yang telah berimplikasi luas pada penguatan kesadaran politik rakyat karena dalam waktu singkat, Mei hingga Oktober 1998, berdiri 80 partai politik baru yang kemudian melonjak menjadi 181 partai menjelang April 1999. Sebanyak 48 partai politik di antaranya dinyatakan sebagai partai politik yang memenuhi syarat mengikuti pemilu pertama era reformasi 1999.15 Hasilnya, 21 partai politik berhasil

11 Agus Sutisna, "Politik Penyederhanaan Sistem Kepartaian di Indonesia Pasca Reformasi 1998”, Jurnal Sosio Didaktika: Social Science Education Journal, 2 (2), 2015, hlm. 171

12 Suparman Marzuki, Politik Hukum Hak Asasi Manusia, Erlangga, Yogyakarta, 2014, hlm. 91

${ }^{13}$ Kuswanto, Konstitusionalitas..., Op. Cit., hlm. 157

${ }^{14}$ Ibid

${ }^{15}$ Ibid 
mengirimkan wakil-wakilnya di DPR RI, yaitu: PDIP, Golkar, PPP, PKB, PAN, PBB, Partai Keadilan, PKP, PNU, PDKB, PBI, PDI, PP, PDR, PSII, PNI Front Marhaenis, PNI Massa Marhaen, IPKU, PKU, Masyumi, dan PKD. Dengan hasil ini, sistem multipartai ekstrim juga mewarnai konfigurasi kekuatan-kekuatan politik di parlemen. ${ }^{16}$

Mengantisipasi dampak negatif dari sistem multipartai, Pasal 39 ayat (3) Undang-Undang No. 3 Tahun 1999 memberlakukan ketentuan yang lazim dikenal dengan electoral threshold yang menentukan bahwa untuk mengikuti pemilu selanjutnya, "partai politik harus memiliki sekurang-kurangnya 2\% dari jumlah kursi DPR, atau sekurang-kurangnnya 3\% kursi dari jumlah kursi DPRD I atau DPRD II yang tersebar sekurang-kurangnya di $1 \frac{1}{2}$ jumlah Provinsi dan di $1 \frac{1}{2}$ jumlah Kabupaten/Kota di seluruh Indonesia."17

Pada masa ini telah diberlakukan electoral threshold 2\%, sehingga partai yang memperoleh suara di bawah $2 \%$ tidak dapat ikut pemilu berikutnya kecuali misalnya dengan mengubah nama partai. ${ }^{18}$ Pada pemilu tahun 1999, hanya 6 (enam) partai politik yang berhasil lolos electoral threshold yaitu: PDIP $(31,12 \%)$, Golkar (25,97\%), PPP (12,55\%), PKB (11,03\%), PAN (7,36\%), dan PBB (2,81\%). ${ }^{19}$

Berdasarkan aturan main, 6 partai tersebut yang otomatis menjadi peserta pemilu 2004. Sementara 42 partai yang tidak lolos electoral threshold, undangundang mengatakan mereka bisa mengikuti pemilu tahun 2004 asalkan bergabung dengan partai lain. Dalam hal ini, Pasal 143 ayat (2) Undang-Undang No. 12 Tahun 2003 menggariskan 3 skenario: 20

a. Bergabung dengan partai politik yang lolos electoral threshold;

b. Bergabung dengan partai lain yang tidak lolos electoral threshold, kemudian menggunakan nama dan tanda gambar salah satu partai; dan

c. Bergabung dengan partai yang tidak lolos electoral threshold, kemudian menggunakan nama dan gambar baru.

16 Ronny Basista, "Penyederhanaan Sistem Kepartaian dan Efektivitas Pemerintahan", Makalah disampaikan pada seminar FISIP-UT tanggal 23 Februari 2011, hlm. 3

${ }^{17}$ Kuswanto, Konstitusionalitas..., Op. Cit., hlm. 158

${ }^{18}$ Ronny Basista, Penyederbanaan..., Op., Cit., hlm. 4

${ }^{19}$ Saldi Isra, Pemilu dan Pemulihan Daulat Rakyat, Themis Publishing, Jakarta, 2017, hlm. 45

${ }^{20}$ Ibid 
Dalam kaitan upaya penyederhanaan sistem kepartaian ini, beberapa langkah dan strategi kebijakan telah coba diterapkan dalam perhelatan demokrasi elektoral Indonesia sejak pemilu 2004. Kajian yang dilakuan penulis, setidaknya ada 5 jalan yang pernah ditempuh untuk menyederhanakan sistem kepartaian di Indonesia. (1) Memperberat syarat pendirian partai; (2) Memperberat syarat parpol memperoleh badan hukum; (3) Memperberat syarat parpol untuk ikut Pemilu; (4) menerapkan ambang batas bagi partai politik untuk dapat mengikuti pemilu (electoral threshold); (5) dan Menerapkan ambang batas bagi partai politik untuk dapat mengirimkan wakilnya di parlemen (parliamentary threshold).

\section{Memperberat Syarat-Syarat Pendirian Partai Politik}

Pengaturan pendirian partai politik dalam rangka penyederhanaan partai politik didasari sejumlah argumen sebagai berikut. Pertama, penggunaan hak/kebebasan berserikat sebagai dasar legitimasi dalam tindakan pendirian partai politik oleh warga negara harus dilakukan secara reasonable. Negara wajib melakukan pengaturan agar pendirian partai politik tidak dimotivasi oleh kepentingan politik sempit dan kepentingan politik jangka pendek karena jika hal itu dibiarkan maka akan potensi menimbulkan penyalahgunaan hak/kebebasan berserikat. Kedua, menjaga integritas partai politik dalam rangka sustainabilitas atau keberlanjutan fungsionalnya. Sustainabilitas partai politik adalah persoalan krusial dalam pendirian partai politik karena partai politik sebagai subjek hukum adalah badan hukum yang secara teori untuk tidak terbatasi usianya oleh waktu. ${ }^{21}$

Bab II Pasal 2 Undang-Undang No. 31 Tahun 2002 tentang Partai Politik menghadirkan pengaturan terhadap eksistensi partai politik di era sistem multipartai electoral mengenai pendirian/pembentukan partai politik, sebagai berikut: 22

1) Partai politik didirikan dan dibentuk oleh sekurang-kurangnya 50 (lima puluh) orang warga negara Republik Indonesia yang telah berusia 21 (dua puluh satu) tahun dengan akta notaris;

2) Akta notaris sebagaimana dimaksud ayat (1) harus memuat anggara dasar dan anggaran rumah tangga disertai kepengurusan tingkat nasional.

${ }^{21}$ Ibid

22 Undang-Undang Nomor 31 Tahun 2002 tentang Partai Politik 
Kemudian Pasal 1 angka 1 Undang-Undang No. 2 Tahun 2008 jo. Pasal 1 angka 1 Undang-Undang No. 2 Tahun 2011 mendefinisikan "partai politik adalah organisasi yang bersifat nasional dan dibentuk oleh sekelompok warga negara Indonesia secara sekarela atas dasar kesamaan kehendak dan cita-cita untuk memperjuangkan dan membela kepentingan politik anggota, mansyarakat, bangsa, dan negara, serta memelihara keutuhan NKRI berdasarkan Pancasila dan UUD NRI 1945." Pasal 2 Undang-Undang No. 2 Tahun 2008 menentukan syarat pendirian/pembentukan partai politik sebagai berikut: ${ }^{23}$

1) Partai politik didirikan dan dibentuk paling sedikit 50 (lima puluh) orang warga negara Indonesia yang telah berusia 21 (dua puluh satu) tahun, dan menyertakan 30\% (tiga puluh perseratus) keterwakilan perempuan, dengan akta notaris.

2) Akta notaris harus memuat AD dan ART serta kepengurusan partai politik tingat pusat.

3) AD memuat paling sedikit:
a. Asas dan ciri partai politik;
b. Visi dan misi partai politik;
c. Nama, lambang dan tanda gambar partai politik;
d. Tujuan dan fungsi partai politik;
e. Organisasi, tempat kedudukan, dan pengambilan keputusan;
f. Kepengurusan partai politik;
g. Peraturan dan keputusan partai politik;
h. Pendidikan partai politik, dan
i. Keuangan partai politik.

4) Kepengurusan partai politik tingkat pusat disusun dengan menyertakan paling rendah $30 \%$ (tiga puluh perseratus) keterwakilan perempuan.

Ketentuan tersebut kemudian diubah berdasarkan Undang-Undang No. 2 Tahun 2011. Pasal 1 angka 2 Undang-Undang No. 2 Tahun 2011 menentukan perubahan tersebut sebagai berikut: "partai politik didirikan dan dibentuk oleh paling sedikit 30 orang warga negara Indonesia yang telah berusia 21 tahun atau sudah menikah dari setiap provinsi. Kemudian selanjutnya, ditambahkan ketentuan bahwa partai politik didaftarkan oleh paling sedikit 50 pendiri yang mewakili seluruh partai politik dengan akta notaris. Pada pendiri dan pengurus partai politik berlaku ketentuan larangan merangkap jabatan sebagai anggota partai politik lain". ${ }^{24}$

\footnotetext{
${ }^{23}$ Kuswanto, Konstitusionalitas..., Op. Cit., hlm. 188

${ }^{24}$ Ibid
} 
Perubahan juga terjadi pada ketentuan syarat anggaran dasar partai politik, yaitu selain beberapa materi muatan di atas, juga ditambahkan beberapa materi berupa mekanisme penyelesaian perselisihan internal partai politik; mekanisme pemberhentian anggota partai politik; sistem kaderisasi; dan mekanisme rekrutmen keanggotaan partai politik dan jabatan partai politik. ${ }^{25}$

Penjelasan umum Undang-Undang No. 2 Tahun 2011 tentang perubahan atas Undang-Undang No. 2 Tahun 2008 tentang partai politik menegaskan bahwa, untuk memperkuat dan mengefektifkan sistem presidensial, paling tidak dilakukan pada empat hal, yaitu pertama, mengkondisikan terbentuknya sistem multipartai sederhana; kedua, mendorong terciptanya pelembagaan partai politik yang demokratis dan akuntabel; ketiga, mengkondisikan terbentuknya kepemimpinan partai yang demokratis dan akuntabel; dan keempat, mendorong penguatan basis dan struktur kepartaian pada tingkat masyarakat. Akan tetapi, tampaknya perubahan yang dilakukan terhadap Undang-Undang No. 2 Tahun 2011 tidak terlalu signifikan. Syarat pembentukan partai politik yang tadinya 50 orang, kemudian diturunkan menjadi 30 orang. ${ }^{26}$

\section{Memperberat Syarat Partai Politik Mendapatkan Badan Hukum}

Undang-Undang No. 31 Tahun 2002 tentang Partai Politik diterbitkan untuk menggantikan Undang-Undang No. 2 Tahun 1999 yang dipandang tidak sesuai lagi dengan perkembangan msyarakat dan ketatanegaraan. Dalam penjelasan undang-undang a quo dinyatakan bahwa sistem kepartaian kita menganut sistem multipartai sederhana yang dilakukan dengan menerapkan syarat kualitatif ataupun syarat kuantitatif, baik dalam pembentukan partai politik maupun dalam penggabungan partai politik yang ada. ${ }^{27}$

Pasal 2 ayat (3) Undang-Undang No. 31 Tahun 2002 tentang Partai Politik, menentukan "Partai politik sebagaimana dimaksud pada ayat (1) harus didaftarkan pada departemen kehakiman dengan syarat:"28

\footnotetext{
${ }^{25}$ Ibid

${ }^{26}$ Ni'matul Huda dan Imam Nasef, Penataan..., Op. Cit., hlm. 40

${ }^{27}$ Erfandi, Parliamentary Threshold dan HAM Dalam Hukum Tata Negara Indonesia, Setara Press, Malang, 2014,

${ }^{28}$ Kuswanto, Konstitusionalitas..., Op. Cit., hlm. 190
} hlm. 104 
1) Memiliki akta notaris pendirian partai politik sesuai dengan UUD NRI 1945 dan peraturan perundang-undangan lainnya;

2) Mempunyai kepengurusan sekurang-kurangnya 50\% (lima puluh persen) dari jumlah provinsi, 50\% (lima puluh persen) dari jumlah Kabupaten/Kota pada setia Provinsi yang bersangkutan, dan 25\% (dua puluh lima persen) dari jumlah Kecamatan pada setiap Kabupaten/Kota yang bersangkutan;

3) Memiliki nama, lambang, dan tanda gambar yang tidak mempunyai permasaan pada pokoknya atau keseluruhan dengan nama, lambang, dan tanda gambar partai lain;

4) Mempunyai kantor tetap (alamat secretariat yang jelas ditujukan dengan dokumen tang sah) dari pusat samapai tingkat Kabupaten/Kota; dan

5) Menteri Kehakiman mengesahkan partai politik yang memenuhi syarat sebagai badan hukum paling lambat 30 (tiga puluh) hari sejak penerimaan pendaftaran dan mengumumkan dalam Berita Negara Republik Indonesia.

Ketentuan terkait syarat untuk memperoleh status badan hukum partai politik diubah dalam Pasal 3 Undang-Undang No. 2 Tahun 2008. Menentukan bahwa partai politik harus didaftarkan ke Departmen Hukum dan HAM untuk menjadi badan hukum. Syarat untuk melakukan pendaftaran adalah partai politik harus mempunyai: 29

1) Akta notaris pendirian partai politik;

2) Nama, lambang, atau tanda gambar yag tidak mempunyai persamaan pokoknya atau keseluruhannya dengan nama, lambang, atau tanda gambar yang telah dipakai secara sah oleh partai politik lain sesuai dengan peraturan perundang-undangan;

3) Kantor tetap;

4) Kepengurusan paling sedikit $60 \%$ (enam puluh perseratus) dari jumlah Provinsi, 50\% (lima puluh perseratus) dari jumlah Kabupaten/Kota pada setiap Provinsi yang bersangkutan, dan 25\% (dua puluh lima perseratus) dari jumlah Kecamatan pada setiap Kabupaten/Kota pada daerah yang bersangkutan, dan;

5) Memiliki rekening atas nama partai politik.

Berdasarkan Undang-Undang No. 2 Tahun 2011 tentang partai politik, dilakukan perubahan terhadap syarat di atas dengan menaikan ambang batas kepengurusan tingkat Kabupaten/Kota pada tiap Provinsi: "kepengurusan pada setiap Provinsi paling sedikit 75\% dari jumlah Kabupaten/Kota pada Provinsi yang bersangkutan dan paling sedikit 50\% dari jumlah Kecamatan pada Kabupaten/Kota yang bersangkutan." Pengaturan ini ditujukan pada perluasan ketersebaran

${ }^{29}$ Erfandi, Parliamentary..., Op. Cit., hlm. 107 
kepengurusan partai politik di tingkat Kabupaten/Kota dalam satu Provinsi.

Perubahan lain adalah pada keberadaan kantor tetap yang lebih rinci: "kantor tetap pada tingkatan pusat, Provinsi, dan Kabupaten/Kota sampai tahapan akhir pemilu". 30

\section{Memperberat Syarat Partai Politik Untuk Mengikuti Pemilu}

Ketentuan peralihan Pasal 29 Undang-Undang No. 31 Tahun 2002 mengatur hal-hal sebagai berikut: ${ }^{1}$

1) Partai politik yang menurut Undang-Undang No. 2 Tahun 1999 tentang partai politik telah disahkan sebagai badan hukum oleh Menteri Kehakiman Republik Indonesia diakui keberadaannya dan wajib menyesuaikan dengna ketentuan undang-undang ini selambat-lambatnya 9 (Sembilan) bulan sejak berlakunya undang-undang ini;

2) Partai politik yang tidak memenuhi ketentuan sebagaimana dimaksud pada ayat (1) dibatalkan keabsahannya sebagai badan hukum dan tidak diakui keberadaannya menurut undang-undang ini; dan

3) Dengan berlakunya undang-undang ini, penyelesaian perkara partai politik yang sedang dalam proses peradilan menyesuaikan dengan ketentuan undang-undang ini.

Selanjutnya dilakukan peubahan dalam ketentuan peralihan Pasal 51 Undang-Undang No. 2 Tahun 2008 diatur hal-hal sebagai berikut: ${ }^{32}$

1) Partai politik yang telah disahkan sebagai badan hukum berdasarkan Undang-Undang No. 31 Tahun 2002 tentang partai politik tetap diakui keberadaannya;

2) Partai politik sebagaimana dimaksud ayat (1) wajib melaksanakan ketentuan sebagaimana dimaksud dalam pasal 2 ayat (5) paling lama pada forum tertinggi pengambilan keputusan partai politik pada kesempatan pertama sesuai denga AD dan ART setelah undang-undang ini diundangkan;

3) Partai politik yang sudah mendaftarkan diri ke Departemen sebelum undang-undang ini diundangkan, diproses sebagai badan hukum menurut undang-undang ini;

4) Penyelesaian perkara partai politik yang sedang dalam proses pemeriksaan di pengadilan dan belum diputus sebelum undang-undang ini diundangkan, penyelesaiannya diputus berdasarkan Undang-Undang No. 31 Tahun 2002 tentang partai politik; dan

5) Perkara partai politik yang telah didaftarkan ke pengadilan sebelum undang-undang ini diundangkan dan belum diproses, perkara dimaksud diperiksa dan diputus berdasarkan undang-undang ini.

\footnotetext{
${ }^{30}$ Kuswanto, Konstitusionalitas..., Op. Cit., hlm. 109-191

31 Lihat Undang-Undang No 31 Tahun 2002 tentang Partai Politik

${ }^{32}$ Kuswanto, Konstitusionalitas..., Op. Cit., hlm. 201
} 
Pasal 1 angka 15 Undang-Undang No. 2 Tahun 2011 mengubah ketentuan Pasal 51 No. 2 Tahun 2008 sehingga ketentuannya yang saat ini berlaku menjadi: ${ }^{3}$

1) Partai politik yang telah disahkan sebagai badan hukum berdasarkan Undang-Undang No. 2 Tahun 2008 tentang partai politik tetap diakui keberadaannya dengan kewajiban melakukan penyesuaian menurut undang-undang ini dengan mengikuti verifikasi:

a. Verifikasi partai politik sebagaimana dimaksud ayat (1) dan partai politik yang dibentuk setelah undang-undang ini diundangkan, selesai paling lambat $2 \frac{1}{2}$ (dua setengah) tahun sebelum hari pemungutan suara pemilu;

b. Dalam hal partai politik sebagaimana dimaksud pada ayat (1) tidak memenuhi syarat verifikasi, keberadaaan partai politik tersebut tetap diakui sampai dilantiknya anggota DPR, DPRD Provinsi, dan DPRD Kabupaten/Kota hasil pemilu tahun 2014; dan

c. Anggota DPR, DPRD Provinsi, dan DPRD Kabupaten/Kota dari partai politik sebagaimana dimaksud ayat (b) tetap diakui keberadaannya sebagai anggota DPR, DPRD Provinsi, DPRD Kabupaten/Kota sampai akhir periode keanggotaannya.

2) Perubahan AD sebagiamana dimaksud dalam Pasal 2 ayat (4) huruf g, h, i, dan huruf $m$ wajib dipenuhi pada kesempatan pertama diselenggarakan forum tertinggi pengambilan keputusan partai politik sesuai dengan AD dan ART setelah undang-undang ini diundangkan;

3) Dihapus;

4) Penyelesaian perkara partai politik yang sedang dalam proses pemeriksaan di pengadilan dan belum diputus sebelum undang-undang ini diundangkan, penyelesaiannya diputus berdasarkan Undang-Undang No. 2 Tahun 2008 tentang partai politik; dan

5) Perkara partai politik yang telah didaftarkan ke pengadilan sebelum undang-undang ini diudangkan dan belum diproses, perkara dimaksud diperiksa dan diputus berdasarkan undang-undang ini.

Ketentuan tentang verifikasi partai politk pada hakikatnya memiliki ratio legis untuk menegakan ketentuan tentang syarat pendirian partai politik dan syarat untuk memperoleh status badan hukum partai politik. Dengan terjadinya perubahan undang-undang, dan perubahan tersebut juga mengubah syarat mengenai pendirian partai politik dan syarat untuk mendapat status badan hukum partai politik maka ketentuan tentang verifikasi tersebut bertujuan untuk memastikan bahwa partaipartai akan mematuhi ketentuan tersebut. Hal ini berimplikasi terhadap kebijakan 
penyederhanaan partai politik sangat signifikan karena partai politik yang tidak lolos verifikasi akan berakhir eksistensinya pada 2014. ${ }^{34}$

\section{Menerapkan Ambang Batas Bagi Partai Politik Untuk Mengikuti Pemilu (Electoral Threshold)}

Pada Pemilu 2004, jumlah partai politik peserta pemilu berkurang setengahnya menjadi 24 (dua puluh empat) partai politik di bandingkan pemilu 1999. Hal ini dimungkinkan karena muncul ketentuan yang memperberat persyaratan pendirian partai politik sebagai badan hukum dalam partai politik sebagai peserta pemilu. Demikian pula dengan jumlah partai politik di parlemen, meski tidak cukup signifikan, mengalami penurunan jumlah menjadi 17 partai politik dan 7 di antaranya berhasil lolos dari ambang batas pemilu (electoral threshold) yang mulai diberlakukan. Dari 24 partai politik peserta pemilu tahun 2004, sebanyak 16 partai politik berhasil meraih kursi di DPR. Akan tetapi, hanya 7 partai yang berhasil melampaui electoral threshold dan berhak langsung menjadi peserta pemilu 2009. Konfigurasi kursi di DPR juga berarti tidak ada partai yang dapat mencapai jumlah kursi mayoritas. Komposisi DPR hasil pemilu 2004 tertinggi diperoleh Partai Golkar hanya 128 kursi, disusul PDI-P 109 kursi, Partai Demokrat 55 kursi, PAN 53 kursi, PKS 52 kursi, PBR 14 kursi, PDS 13 kursi, dan PBB 11 kursi. Sedangkan partai lain memperoleh di bawah 10 kursi. ${ }^{35}$

\section{Menerapkan Ambang Batas Partai Politik Untuk Dapat Mengirimkan Wakilnya Di Parlemen (Parliamentary Threshold)}

Selain memberlakukan electoral threshold untuk menjadi peserta pemilu 2009, Undang-Undang No. 10 Tahun 2008 juga mencantumkan ambang batas baru yang dikenal dengan istilah ambang batas parlemen (parliamentary threshold). Jika electoral threshold basis perhitungannya berdasarkan perolehan jumlah kursi, parliamentary threshold dihitung berdasarkan jumlah suara sah yang diraih partai. Parliamentary threshold juga menjadi ambang batas untuk meraih kursi di parlemen, berbeda dengan electoral threshold yang berfungsi sebagai ambang batas untuk

\footnotetext{
${ }^{34}$ Ibid

35 Hanta Yuda, Presidensialisme Setengah Hati: Dari Dilema ke Kompromi, Gramedia Pustaka Utama, Jakarta, 2010, hlm. 127
} 
mengikuti pemilu berikutnya. Dalam hal ini, untuk mewujudkan "simple multiparty", diterapkan pemberlakuan parliamentary threshold atau ambang batas parlemen sebesar 2,5\% perolehan suara sah secara nasional. Melalui penerapan ambang batas ini, diharapkan permasalahan yang selalu muncul menjelang dilaksanakannya pemilu dapat dieliminasi, dan upaya untuk mewujudkan simple multiparty dapat dilakukan secara gradual tanpa melanggar hak setiap warga negara untuk berkumpul dan berserikat sebagaimana dijamin oleh UUD 1945. ${ }^{36}$

Menurut Laporan Khusus Pengambilan Keputusan RUU tentang pemilu anggota DPR, DPD, dan DPRD pada rapat Paripurna DPR RI, ambang batas 3\% perolehan suara partai politik peserta pemilu 2004 sebagaimana yang diatur dalam Undang-Undang No. 12 Tahun 2003 tetap berlaku dalam undang-undang ini. Namun demikian terdapat ketentuan peralihan bahwa bagi partai politik peserta pemilu 2004 yang memiliki kursi di DPR dapat langsung menjadi peserta pemilu 2009. Hal itu merupakan konsekuensi dari penerapan parliamentary threshold sebesar 2,5\% yang berlaku nasional untuk DPR RI pada hasil pemilu 2009.37

Masuk pada pemilu 2009 jumlah partai politik peserta pemilu kembali melonjak dari angka 24 partai politik peserta pemilu 2004 menjadi 38 partai politik, ditambah dengan partai politik lokal di Aceh sebanyak 6 partai. Dari 38 partai politik tersebut kemudian 9 partai lolos dari ketentuan parliamentary threshold yang mulai diberlakukan menggantikan ketentuan electoral threshold yang dianggap "kurang adil" dan tidak tepat dalam masyarakat yang serba majemuk dan sistem pemilu proporsional seperti di Indonesia. ${ }^{38}$ Berdasarkan ketetapan dalam Bab XIII Pasal 204-212, UU No. 10 Tahun 2008 tentang Pemilihan Umum Anggota DPR, DPD dan DPRD, maka hanya 9 partai politik saja yang bisa meloloskan wakilnya sebagai anggota DPR. Partai lainnya, meskipun memperoleh suara/kursi, dianggaap tidak memperolehnya (hangus) karena adanya klausul parliamentary

${ }^{36}$ Ibid., hlm. 4

${ }^{37}$ Laporan Panitia Khusus Dalam Rangka Pembicaraan Tingkat II/Pengambilan Keputusan Rancangan Undang-Undang tentang Pemilu Anggota DPR, DPD, dan DPRD menjadi Undang-Undang Pada Rapat Paripurna DPR RI, Kamis 28 Februari 2008, hlm. 4

38 Ronny Basista, Penyederbanaan..., Op. Cit., hlm. 5 
threshold 2,5\%. Partai-partai yang berhasil duduk di DPR adalah ${ }^{39}$ Partai Demokrat, P-Golkar, P-PDIP, P-PKS, P-PAN, P-PPP, P-PKB, P- Gerindra, dan P-Hanura.

Sadar akan urgensi agenda penyederhanaan sistem kepartaian, DPR dan Presiden akhirnya sepakat untuk meningkatkan ambang batas parlemen (Parliamentary Threshold) menjadi 3,5\% untuk pemilu 2014. Hal ini tercantum di dalam Pasal 208 UU No. 8 Tahun 2012 tentang Pemilihan Umum Anggota Dewan Perwakilan Rakyat, Dewan Perwakilan Daerah dan Dewan Perwakilan Rakyat Daerah. ${ }^{40}$ Pemilu terakhir 2014, diikuti oleh 12 partai politik peserta pemilu yang berasal dari 9 partai yang lolos parliamentary threshold ditambah 2 partai lama yang berhasil memenuhi ketentuan verifikasi kepesertaan pemilu 2014. Selain itu, pemilu 2014 ini juga masih diikuti oleh 3 partai politik lokal di Aceh. Partai peserta pemilu 2014 di antaranya: Nasdem, PKB, PKS, PDI-P, Golkar, Gerindra, Demokrat, PAN, PPP, Hanura, P-Damai Aceh, P-Nasional Aceh, P-Aceh, P-Bulan Bintang, dan PKPI. ${ }^{11}$ Hasilnya, ada 10 partai politik yang kemudian mampu lolos parliamentary threshold dan masuk di parlemen. Kesepuluh partai ini juga berhak mengikuti pemilu 2019 mendatang, dengan demikian sistem multipartai ekstrim masih akan terus mewarnai kehidupan demokrasi electoral Indonesia ke depan. ${ }^{42}$

Politik Hukum Penentuan Parliamentary Threshold dalam Undang-Undang No. 7 Tahun 2017 Sebagai Upaya Penyederhanaan Sistem Kepartaian di Indonesia

Kenaikan presentase ambang batas parlemen (Parliamentary Threshold) dianggap efektif untuk menyederhanakan sistem kepartaian di parlemen, guna mengefektifkan sistem presidensial. Karena itu, parliamentary threshold menjadi isu yang krusial, mengigat undang-undang tentang pemilu yang lahir pasca amandemen Undang-Undang Dasar 1945 telah membawa misi untuk membangun sistem multipartai sederhana untuk mendukung pemerintahan yang lebih stabil dan efektif dalam mencapai tujuan negara. ${ }^{43}$

\footnotetext{
${ }^{39}$ Ibid.

${ }^{40}$ Adlina Adelia, "Relevansi Ambang Batas Parlemen (Parliamentary Threshold) Dengan Sistem Presidensial di Indonesia”, Tesis, Yogyakarta, 2018, hlm. 171

${ }^{41}$ Ibid., hlm. 143

42 Agus Sutisna, Politik..., Op. Cit., hlm. 171

43 Adlina Adelia, Relevansi..., Op. Cit., hlm. 181
} 
Ketua Panitia Khusus (Pansus) Rancangan Undang-Undang (RUU) pemilu, Lukman Edy menyatakan, ada beberapa opsi mengenai ambang batas parlemen (parliamentary threshold) yang ditawarkan dari seluruh fraksi yang ada di DPR untuk pemilu legislatif 2019, meliputi $0 \%, 3,5 \%, 5 \%, 7 \%$ dan yang terakhir $10 \%$. Dalam Daftar Inventaris Masalah (DIM) RUU Pemilu, Fraksi P-Golkar secara resmi mengusulkan angka ambang batas parlemen mencapai angka 5-10\%.44

Menurut Menteri Dalam Negeri, penerapan ambang batas dibutuhkan untuk menjaga kualitas perwakilan partai politik yang akan menjadi anggota parlemen. Memandang keberadaan Parliamentary Threshold harus dipertahankan guna meningkatkan kualitas, karena yang menentukan partai aspiratif atau tidak, legitimate atau tidak bukanlah DPR, bukan juga pemerintah melainkan rakyat. Memandang hak parrtai politik untuk mengirimkan perwakilan ke parlemen harus diatur melalui ambang batas. ${ }^{45}$

Menurut Tjahjo Kumolo, pemerintah telah mengambil posisi terkait Parliamentary Threshold sebesar 3,5\%. Namun prinsipnya pemerintah ingin menaikan besaran presentase sebesar $4 \%$ hingga 5\%, mengingat Parliamentary Threshold merupakan salah satu instrumen positif dan teruji dalam upaya untuk mampu mengkonsolidasikan fragmentasi kekuatan politik di DPR. Karena itu, pemerintah sangat mengharapkan adanya peningkatan Parliamentary Threshold yang di dalam undang-undang sebelumnya 3,5\% menjadi minimal diposisi $4 \% .{ }^{46}$

Pada perkembangnya, ambang batas DPR ini terdapat beberapa pilihan yaitu: ${ }^{47}$

a. Ambang batas DPR 3,5\% yakni suatu partai politik tertentu harus memenuhi ambang batas perolehan paling minimal sebesar 3,5\% untuk diikutkan dalam penentuan perolehan kursi Anggota DPR;

b. Ambang batas DPR 4\% yaitu suatu partai politik tertentu harus memenuhi ambang batas perolehan suara paling minimal $4 \%$ untuk diikutkan dalam penentuan Anggota DPR, dan;

${ }^{44}$ Rakhmat Nur Hakim, "Ini Lima Opsi Ambang Batas Parlemen Pemilu 2019”, dalam https:/ / nasional.kompas. com/read/2017/01/11/13173381/.iini.lima.opsi.ambang.batas.parlemen.pemilu.2019, diakses tanggal 12 Desember 2017

${ }^{45}$ Adlina Adelia, Op. Cit., hlm. 183

46 Ibid

${ }^{47}$ Laporan Pansus Rancangan Undang-Undang tentang Pemilu Dalam Rapat Paripurna DPR Ri, Kamis 20 April 2017, hlm. 967 
c. Ambang batas DPR 6\% yaitu suatu partai politik tertentu harus memenuhi ambang batas perolehan suara paling minimal 5\% untuk diikutkan dalam penentuan perolehan kursi Anggota DPR.

Menurut Pimpinan Panitia Khusus (Pansus) Muhammad Lukman Edi, dalam laporan panitia khusus Rancangan Undang-Undang (RUU) pemilu, ada isu-isu krusial yang diputuskan oleh pansus pada 12 Juli 2017 melalui rapat internal untuk diformulasikan ke bentuk 5 paket opsi yang kemudian diserahkan pengambilan keputusannya ditingkat Rapat Paripurna DPR RI. Adapun paket opsi tersebut adalah sebagai berikut: 48

Paket A: Ambang batas presiden $20 \%$ atau $25 \%$, ambang batas parlemen $4 \%$, sistem pemilihan umum proporsional terbuka, alokasi kursi per Dapil 3 sampai dengan 10 dan metode konversi suara Sainte Lague Murni.

Paket B : Ambang batas presiden $0 \%$, ambang batas parlemen $4 \%$, sistem pemilihan umum proporsional terbuka, alokasi kursi per Dapil 3 sampai 10 dan metode konversi suara Kuota Hare.

Paket C: Ambang batas presiden $10 \%$ atau $15 \%$, ambang batas parlemen $4 \%$, sistem pemilihan umum proporsional terbuka, alokasi kursi per Dapil 3 sampai dengan 10 dan metode konversi suara Kuota Hare.

Paket D: Ambang batas presiden $10 \%$ atau $15 \%$, ambang batas parlemen $5 \%$, sistem pemilihan umum proporsional terbuka, alokasi kursi per Dapil 3 sampai dengan 8 dan metode konversi suara Sainte Lague Murni.

Paket E : Ambang batas presiden $20 \%$ atau 25\%, ambang batas parlemen 3,5\%, sistem pemilihan umum proporsional terbuka, alokasi kursi per Dapil 3 sampai dengan 10 dan metode konversi suara Kuota Hare.

Selanjutnya terdapat beberapa pendapat mini dari Fraksi-Fraksi yang ada di parlemen hasil dari rapat internal yang di lakukan oleh Pansus. Pertama, Fraksi PDI-P melalui wakilnya di parlemen Arif Wibowo, menanggapi opsi-opsi yang sudah disampaikan menyangkut 5 paket isu krusial sebagai kesepakatan terakhir hasil Rapat Internal Pansus Pemilu, Fraksi PDI Perjuangan DPR RI memutuskan untuk memilih opsi paket A menjadi bagian dari keseluruhan hasil pembahasan Rancangan Undangundang Pemilu untuk dilanjutkan pada pembicaraan Tingkat II atau pengambilan keputusan dalam Rapat Paripurna DPR RI. Opsi paket A yang dimaksud, yaitu: ${ }^{49}$

${ }^{48}$ Risalah Rapat Kerja Pansus Rancangan Undang-Undang tentang Penyelenggaraan Pemilu, Rapat Kerja ke-19, Kamis 13 Juli 2017, hlm. 801

49 Ibid., hlm. 805 

a. Ambang batas Presiden $20 \%$ kursi DPR-RI atau $25 \%$ suara sah secara Pemilu nasional;
b. Ambang batas parlemen $4 \%$;
c. Sistem Pemilu proposional daftar terbuka;
d. Alokasi kursi per daerah pemilihan sekurang-kurangnya 3 kursi, sebanyak- banyaknya 10 kursi, dan;
e. Metode konversi suara menjadi kursi adalah santai lagu murni.

Kemudian Rambe Kamarul Zaman dari Fraksi Partai Golkar, Secara prinsip Fraksi Partai Golkar berpandangan bahwa dalam membahas kembali undangundang pemilu harus menjadi bagian dari agenda konsolidasi demokrasi di Indonesia. Sehingga upaya rekontruksi aturan pemilu, lebih ditujukan dalam rangka menata bangunan sistem politik Indonesia bukan untuk membongkarnya. Setidaknya prioritas dan prinsip di atas tergambar pada Pasal 4 Rancangan Undang-Undang Pemilu ini yang menyatakan bahwa pengaturan penyelenggaraan pemilu bertujuan untuk: 50

a. Memperkuat sistem presidential;

b. Mewujudkan Pemilu yang adil dan berintergritas;

c. Menyederhanakan dan menjamin konsistensi pengaturan sistem Pemilu; dan

d. Mencegah duplikasi pengaturan dan ketidakpastian hukum pengaturan Pemilu dan mewujudkan efisiensi dan efektivitas dalam penyelenggaraan Pemilu.

Fraksi Partai Golkar berpendapat bahwa, kenaikan Parliamentary Threeshold adalah demi membangun dan mengembangkan sebuah kehidupan politik yang berusaha menciptakan kompatibilitas, antara sistim kepartaian dan kabinet yang terbentuk dengan pemerintahan presidensial yang dianut Indonesia. Dalam suasana tegaknya chek and balanceses di antara lembaga negara yang dewasa ini menjadi kebutuhan mendesak, yang harus diwujudkan bukan untuk memberangus keberagaman seperti yang dilontarkan pihak yang tidak setuju selama ini. Fraksi Parta Golkar menyetujui ambang batas parlemen sebesar 4\%, dengan pilihan paket A seperti PDI-P. 51

Fraksi PAN menilai alasan penyederhanaan sistem kepartaian di Indonesia dengan menerapkan kenaikan besaran Parliamentary Threeshold, secara berlebihan

\footnotetext{
${ }^{50}$ Ibid

${ }^{51}$ Ibid., hlm. 808
} 
adalah kurang tepat, karena justru akan meminggirkan keberadaan partai-partai kecil dan menengah yang juga mendapatkan suara sah dari rakyat. Harus disadari bangsa Indonesia terdiri dari atas beragam suku bangsa yang terangkum dalam keBinekaan, sehingga dalam penyusunan undang- undang harus mengadopsi hal tersebut. Keinginan untuk menyederhanakan partai tidak boleh mengorbankan keragaman suku bangsa ini. Untuk itu fraksi PAN memandang besaran ambang batas ini cukup 3,5\% atau menjadi $4 \%$.Fraksi PAN masih belum menetapkan pilihannya terhadap 5 paket isu krusial, masih menaruh pilihannya pada Paket B ataupun Paket $C$ yang sesuai dengan pendapat dari Fraksi PAN. ${ }^{52}$

Pendapat Akhir Mini yang selanjutnya disampaikan oleh Ahmad Baidowi dari Fraksi PPP pada Rapat Kerja Pansus DPR RI Pada 13 Juli 2017, Kaitannya dengan Parliamentary Threeshold, pada awalnya Fraksi PPP berkeinginan konsistensi dalam penerapan Parliamentary Threeshold yaitu 3,5\%. Namun dalam perkembangannya PPP memaklumi dan bisa memahami keinginan dari sebagian bahkan mayoritas dari fraksi dan pemerintah adanya kenaikan angka Parliamentary Threeshold menjadi $4 \%$ dalam Pemilu 2019, yang dalam hal ini mengalami kenaikan sekitar $0,5 \%$ dari Pemilu sebelumnya. ${ }^{53}$

Fraksi Partai NasDem berpendapat terhadap ambang batas DPR RI, secara tulus dengan alasan agar memperkuat lembaga ketatanegaraan Republik Indonesia khususnya DPR RI, pada awalnya Fraksi Nasdem mengusulkan untuk meningkatkan ambang batas Parlemen dari 3,5\% yang berlaku pada Pemilihan Umum 2014 menjadi 7\% pada pemilu 2019. Akan tetapi melalui pembicaraan, diskusi, negosiasi, lobby dan kerjasama politik untuk kebaikan umum, untuk kepentingan Indonesia, menyepakati, dengan memperhatikan semua argumentasi fraksi yang lain untuk menyetujui ambang batas parlemen sebesar $4 \% .54$

Setelah melewati konfigurasi politik dan loby-loby yang dilakukan oleh Fraksi-Fraksi yang ada di parlemen, maka kesepakatan yang terbangun adalah mengesahkan ambang batas (parliamentary threshold) bagi partai politik yang akan

\footnotetext{
${ }^{52}$ Ibid., hlm. 814

53 Ibid., hlm. 821

${ }^{54}$ Ibid., hlm. 823
} 
menempatkan wakilnya di DPR sebasar 4\%. Hal ini tertuang dalam Pasal 414 ayat

(1) Undang-Undang No. 7 Tahun 2017 tentang pemilu, yang berbunyi: "Partai Politik Peserta Pemilu harus memenuhi ambang batas perolehan suara paling sedikit $4 \%$ (empat persen) dari jumlah suara sah secara nasional untuk diikutkan dalam penentuan perolehan kursi anggota DPR". Ketentuan ambang batas ini mengalami kenaikan $0,5 \%$ dari pemilu 2014. Sehingga, bagi partai politik yang ingin menempatkan wakilnya di DPR harus memiliki suara melampaui parliamentary threshold $4 \%$.

\section{Penutup}

Berdasarkan beberapa uraian di atas dapat disimpulkan beberapa hal, pertama, tingginya angka pertumbuhan partai politik peserta pemilu pasca reformasi sebagai konsekuensi dari perlindungan konstitusional atas kebebasan berserikat berimplikasi pada stabilitas sistem pemerintahan presidensil di Indonesia. Hal ini juga menjadi kontra produktif dengan cita-cita reformasi yang hendak memperkuat bangunan sistem presidensil di Indonesia. Karena itu upaya penyederhanaan sistem kepartaian di Indonesia dilakukan. Beberapa kebijakan yang ditempuh yaitu menerapkan pemberatan pendirian partai politik; memperberat syarat bagi partai politik dalam memperoleh status badan hukum, memperberat partai politik yang akan mengikuti pemilu melalui verifikasi, menerapkan electoral threshold, dan menerapkan ambang batas parlemen (parliamentary threshold). Kedua, penerapan parliamentary threshold dianggap efektif untuk menyederhanakan sistem kepartaian di parlemen, guna mengefektifkan sistem presidensial, karena itu, melalui UndangUndang Nomor 7 Tahun 2017 tentang Pemilihan Umum, ketentuan parliamentary threshold ditentukan angka baru sebesar $4 \%$, karena dinilai angka 3,5\% pada pemilu 2014 belum mampu menyederhanakan sistem kepartaian di Indonesia. Penerapan ambang batas $4 \%$ ini diharapkan mampu setidaknya membuat partai-partai yang masuk ke parlemen semakin ramping agar sistem presidensial yang di terapkan di Indonesia menjadi lebih murni dan loby-loby antar pemerintah dan DPR yang sering mengalami deadlock akan terselamatkan dengan angka ambang batas $4 \%$. Kemudian tujuan dari penelitian ini yang mengharapkan terciptanya sistem multipartai sederhana (moderat multiparty system) akan terwujud. 


\section{Daftar Pustaka}

\section{Buku}

Erfandi, Parliamentary Threshold dan HAM Dalam Hukum Tata Negara Indonesia, Setara Press, Malang, 2014.

Fahmi, Khairul, Pemilihan Umum Dalam Transisi Demokrasi, Cetakan Pertama, PT RajaGrfindo Persada, Jakarta, 2016.

Huda, Ni'matul dan Imam Nasef, Penataan Demokrasi dan Pemilu di Indonesia PascaReformasi, Edisi Pertama Fajar Interpratama Mandiri, Jakarta, 2017.

Isra, Saldi, Pemilu dan Pemulihan Daulat Rakyat, Themis Publishing, Jakarta, 2017.

Kuswanto, Konstitusionalitas Penyederhanaan Partai Politik: Pengaturan Penyederhanaan Partai Politik Dalam Demokrasi Presidensial, Setara Press, Malang, 2016.

Marzuki, Suparman, Politik Hukum Hak Asasi Manusia, Erlangga, Yogyakarta, 2014.

Strong, C.F, Konstitusi-Konstitusi Politik Modern, Cetakan Sepuluh, Nusa Media, Bandung, 2015.

Yuda, Hanta, Presidensialisme Setengah Hati: Dari Dilema ke Kompromi, Gramedia Pustaka Utama, Jakarta, 2010.

\section{Jurnal dan Hasil Penelitian}

Adelia, Adlina, "Relevansi Ambang Batas Parlemen (Parliamentary Threshold) Dengan Sistem Presidensial di Indonesia", Tesis, Yogyakarta, 2018.

Kuswanto, "Penyederhanaan Partai Politik Dalam Sistem Pemerintahan Presidensiil Yang Multipartai", Jurnal Yuridika, Vol. 28, No. 2, 2013.

Sutisna, Agus, "Politik Penyederhanaan Sistem Kepartaian di Indonesia Pasca Reformasi 1998", Jurnal Sosio Didaktika: Social Science Education Journal, 2 (2), 2015.

\section{Website}

Hakim, Rakhmat Nur, "Ini Lima Opsi Ambang Batas Parlemen Pemilu 2019", dalam https://nasional.kompas.com/read/2017/01/11/13173381/.iini.lima.opsi. ambang.batas.parlemen.pemilu.2019, diakses tanggal 12 Desember 2017.

\section{Undang-Undang}

Undang-Undang Dasar Negara Republik Indonesia Tahun 1945

Undang-Undang Nomor 2 Tahun 1999 tentang Partai Politik

Undang-Undang Nomor 3 Tahun 1999 Tentang Pemilu

Undang-Undang Nomor 31 Tahun 2002 tentang Partai Politik 
Undang-Undang Nomor 12 Tahun 2003 tentang Pemilihan Umum Anggota Dewan Perwakilan Rakyat, Dewan Perwakilan Daerah, dan Dewan Perwakilan Rakyat Daerah

Undang-Undang No. 2 Tahun 2008 jo. Undang-Undang No. 2 Tahun 2011 tentang Partai Politik

Undang-Undang Nomor 7 Tahun 2017 tentang Pemilihan Umum

\section{Lain-lain}

Ashiddiqie, Jimly, Membangun Budaya Sadar berkonstitusi Untuk mewujudkan Hukum Yang Demokrasi, Bahasa Orasi Ilmiah Disampaikan Pada peringatan Dies Natalis ke XX1 dan wisuda 2007 Universitas Darul Ulum (Unisda) Lamongan, 29 Desember 2007

Basista, Ronny, "Penyederhanaan Sistem Kepartaian dan Efektivitas Pemerintahan", Makalah disampaikan pada seminar FISIP-UT tanggal 23 Februari 2011

Laporan Panitia Khusus Dalam Rangka Pembicaraan Tingkat II/Pengambilan Keputusan Rancangan Undang-Undang tentang Pemilu Anggota DPR, DPD, dan DPRD menjadi Undang-Undang Pada Rapat Paripurna DPR RI, Kamis 28 Februari 2008

Laporan Pansus Rancangan Undang-Undang tentang Pemilu Dalam Rapat Paripurna DPR Ri, Kamis 20 April 2017

Risalah Rapat Kerja Pansus Rancangan Undang-Undang tentang Penyelenggaraan Pemilu, Rapat Kerja ke-19, Kamis 13 Juli 2017 